\title{
FAKTOR-FAKTOR YANG MEMPENGARUHI PERSISTENSI LABA
}

\author{
Ainun Uswatul Khasanah dan Jasman \\ Fakultas Ekonomi dan Bisnis, Perbanas Institute \\ Email: ainunuswah@gmail.com
}

Diterima 30 April 2019, Disetujui 23 Juli 2019

\begin{abstract}
Abstrak
Penelitian ini bertujuan untuk mengetahui pengaruh volatilitas arus kas independen, volatilitas penjualan, siklus operasi, tingkat utang, ukuran perusahaan dan perbedaan pajak buku dalam persistensi laba. Data yang digunakan dalam penelitian ini diperoleh dari laporan tahunan laporan keuangan perusahaan manufaktur yang terdaftar di Bursa Efek Indonesia periode 2015-2017. Metode pemilihan sampel yang digunakan adalah metode purposive sampling. Teknik analisis yang digunakan dalam penelitian ini menggunakan regresi linier berganda yang meliputi uji normalitas, uji asumsi klasik dan pengujian hipotesis. Total sampel dalam penelitian ini adalah 49 perusahaan. Hasil penelitian menunjukkan bahwa voaltility arus kas I, volatilitas penjualan, tingkat hutang, ukuran perusahaan dan temporer berbeda mempengaruhi persistensi laba. Sementara itu, siklus operasi dan permanen berbeda tidak berpengaruh terhadap persistensi laba.
\end{abstract}

Kata Kunci: Volatilitas Arus Kas, Volatilitas Penjualan, Siklus Operasi, Tingkat Hutang, Ukuran Perusahaan, Perbedaan Pajak Buku.

\begin{abstract}
This research aims to determine the effect of independent cash flow volatility, sale volatility, operating cycle, level of debt, size of firm and book tax differences in earnings persistence. The data used in this research is obtained from the annual report of financial statements on manufacturing companies listed in the Indonesian Stock Exchange period 2015-2017. Sample selection method used is purposive sampling method. Analytical techniques used in this research using multiple linear regression which include normality test, test classic assumptions and hypothesis testing. The total sample in this research is 49 companies. The result shows thatI cash flow voaltility, sale volatility, level of debt, size of firm and temporer different have an affect on earnings persistence. Meanwhile, the operating cycle and permanent different no effect on earnings persistence.
\end{abstract}

Keywords: Cash Flow Volatility, Sale Volatility, Operating Cycle, Level of Debt, Size of Firm, Book Tax Differences. 


\section{PENDAHULUAN}

Menurut Kerangka Konseptual Pelaporan Keuangan, pelaporan keuangan bertujuan untuk menyediakan informasi keuangan tentang entitas pelapor yang berguna untuk investor saat ini dan investor potensial, pemberi pinjaman, dan kreditor lainnya dalam membuat keputusan tentang penyediaan sumber daya kepada entitas. Sedangkan menurut Standar Akuntansi Keuangan (SAK) di Indonesia, tujuan laporan keuangan adalah menyediakan informasi yang menyangkut posisi keuangan, kinerja serta perubahan posisi keuangan suatu perusahaan yang bermanfaat bagi sejumlah besar pemakai dalam pengambilan keputusan ekonomi. Pelaporan Keuangan merupakan wujud pertanggungjawaban manajemen atas pengelolaan sumber daya perusahaan kepada pihak-pihak yang berkepentingan terhadap perusahaan. Sedangkan laporan keuangan itu berisikan informasi yang digunakan sebagai dasar pengambilan keputusan, penilaian kinerja manajemen, penentuan kompensasi manajemen, pemberian deviden kepada pemegang saham dan lain sebagainya. Untuk memudahkan manajer dalam pengambilan keputusan dibutuhkan laba yang berkulitas, yaitu laba yang persisten.

Persistensi laba diartikan sebagai kemampuan suatu perusahaan untuk bertahan dalam kondisi profit di masa depan, dan disebut juga sebagai laba yang berkualitas. Dewi \& putri (2015) berpendapat bahwa laba yang persisten merupakan laba yang tidak fluktuatif dan mencerminkan keberlanjutan laba di masa depan untuk periode yang lama dan berkesinambungan. Schipper \& Vincent (2003) menekankan pentingnya informasi tentang laba bagi investor dan kredtor khususnya untuk pengambilan keputusan pembuatan kontrak (contracting decision), keputusan investasi (investment decision) dam pembuatan standar (standard setter). Keputusan melakukan kontrak yang didasarkan pada persistensi laba yang rendah menyebabkan terjadinya transfer kesejahteraan yang tidak diinginkan oleh semua pihak. Misal, estimasi laba yang terlalu tinggi mengakibaktan kompensasi yang berlebihan kepada manajer atau merekayasa kemampuan melunasi hutang yang sesungguhnya.

Mengingat persistensi laba penting bagi para pengguna laporan keuangan, maka dilakukan analisis atas faktor-faktor yang mempengaruhinya. Dalam penelitian yang dilakukan oleh Fanani (2010) dengan menggunakan variabel volatilitas arus kas, besaran akrual, volatilitas penjualan, tingkat hutang dan siklus operasi terhadap persistensi laba pada perusahaan manufaktur yang terdaftar di BEI pada periode 20012006, dapat disimpulkan bahwa persistensi laba dipengaruhi volatilitas arus kas dari aktivitas operasional, volatilitas penjualan, besaran akrual yang berpengaruh positif dan tingkat hutang berpengaruh negative terhadap persistensi laba. Sedangkan siklus operasi bernilai negatif dan tidak memiliki pengaruh terhadap persistensi laba.

Penelitian mengenai persistensi laba juga dilakukan oleh Dewi \& Putri (2015) dengan tujuan untuk mengetahui pengaruh book tax difference, arus kas operasi, arus kas akrual, dan ukuran perusahaan terhadap persistensi laba sample yang digunakan adalah perusahaan perhotelan dan pariwisata yang terdaftar di BEI tahun 2009-2011. Didalam book tax difference terdapat dua variabel, yaitu perbedaan permanen dan perbedaan temporer. Hasil penelitian yang dilakukan mendapatkan bukti bahwa perbedaan temporer, perbedaan permanen, arus kas operasi dan ukuran perusahaan berpengaruh positif terhadap persistensi laba. Sementara arus kas akrual tidak berpengaruh pada persistensi laba.

Terdapat perbedaan hasil penelitian mengenai faktor-faktor yang mempengaruhi persistensi laba. Didalam penelitian Kusuma \& Sadjiarto (2014), volatilitas arus kas memiliki pengaruh signifikan terhadap persistensi laba, sedangkan dalam penelitian yang dilakukan Purwanti (2010) menjelaskan bahwa tidak ada pengaruh signifikan antara volatilitas arus kas terhadap persistensi laba.

Ketidakpastian dalam lingkungan operasi menujukkan tingkat volatilitas arus kas yang tinggi, yang kemudian menurunkan persistensi laba. Dalam hal ini, kondisi perekonomian yang stabil turut andil dalam menjaga kepastian dalam lingkungan operasi atau dengan kata lain mencegah terjadinya volatilitas arus kas yang tinggi. Selanjutnya adalah volatilitas penjualan, volatilitas penjualan menurut Fanani (2010) adalah apabila volatilitas penjualan rendah dapat menunjukkan kemampuan laba dalam memprediksi aliran kas di masa yang akan datang. Apabila volatilitas penjualan tinggi maka persistensi laba akan rendah. Penelitian yang dilakukan oleh Fanani (2010) membuktikan bahwa volatilitas penjualan berpengaruh negatif terhadap persistensi laba, sedangkan Purwanti (2010) menemukan bahwa volatilitas penjualan berpengaruh positif.

Selain volatilitas arus kas dan volatilitas penjualan, ada variabel yang lain yang digunakan dalam penelitian ini seperti siklus operasi, tingkat hutang, ukuran perusahaan dan book tax differences. Secara teori siklus operasi adalah jumlah waktu dari komitmen atas kas pada pembelian hingga diperoleh 
kas yang berasal dari penjualan barang atau jasa (Subramanyam, 2013). Tingkat hutang akan menimbulkan risiko yang tinggi bagi perusahaan yaitu harus membayar pokok dan bunga pada saat jatuh tempo. Besarnya tingkat hutang akan menyebabkan perusahaan meningkatkan persistensi laba guna mempertahankan kinerja yang baik di hadapan investor dan auditor (Barus \& Rica, 2010).

Besar kecilnya perusahaan menunjukkan seberapa banyak sumber daya yang dimiliki oleh perusahaan yang digunakan untuk menjalankan kegiatan operasi perusahaan. Perusahaan yang besar akan memiliki kestabilan dan operasi yang dapat diprediksi lebih baik, sehingga kesalahan estimasi yang ditimbulkan akan menjadi lebih kecil (Dechow \& Dichev, 2002). Variabel terakhir yang dalam penelitian ini adalah book tax difference, yaitu perbedaan antara laba akuntansi dengan laba fiskal. Ketidaksamaan perhitungan laba yang terjadi setiap tahunnya ini akan berdampak pada pertumbuhan laba suatu periode perusahaan dikarenakan perusahaan harus menyesuaiakan kembali perhitungann laba akuntansinya dengan aturan menurut pajak (Dewi \& Putri, 2015).

\section{KAJIAN TEORI}

\section{Teori Agensi}

Menurut Jensen \& Meckling (1976) teori agensi atau hubungan keagenan merupakan sebuah kontrak yang terjadi antara manajer (agent) dengan pemilik perusahaan (principal). Adanya kepentingan yang berbeda diantara keduanya menimbulkan konflik, dimana seorang manajer (agent) yang mempunyai tanggung jawab untuk mencapai apa yang diinginkan oleh pemilik (principal) namun disisi lain seorang manajer (agent) berusaha untuk meningkatkan kesejahteraan dirinya. Hal ini yang memicu adanya agency problem sehingga pelanggaran seperti memanipulasi laporan keuangan dapat terjadi.

\section{Persistensi Laba}

Persistensi laba merupakan salah satu komponen nilai prediktif laba dan unsur relevansi. Laba dikatakan persisten apabila aliran kas dan laba akrual berpengaruh terhadap laba tahun depan dan perusahaan dapat mempertahankan jumlah laba yang diperoleh saat ini sampai masa yang akan datang. Informasi yang berkaiatan dengan persistensi laba dapat membantu investor dalam menentukan kualitas laba dan nilai perusahaan (Barth \& Hutton, 2003).

Volatilitas Arus Kas Dan Persistensi Laba Laporan arus kas adalah bagian dari laporan keuangan yang melaporkan penerimaan kas, pengeluaran kas dan perubahan kas, hasil dari aktivitas operasi, invetasi dan pendanaan suatu perushaan dalam satu periode akuntansi. Didalam PSAK No 2 tujuan laporan arus kas adalah memberikan informasi tentang arus kas suatu entitas yang berguna bagi para pengguna laporan keuangan sebagai dasar untuk menilai kemampuan entitas dalam menghasilkan kas dan setara kas serta menilai kebutuhan entitas untuk menggunakan arus kas tersebut. Dalam proses pengambilan keputusan ekonomi, para pengguna perlu melakukan evaluasi terhadap kemampuan entitas dalam menghasilkan kas dan setara kas serta kepastian perolehannya. Dechow \& Dichev (2002) berpendapat bahwa volatilitas arus kas mengindikasikan adanya ketidakpastian tinggi dalam lingkungan operasi ditunjukkan oleh volatilitas arus kas yang tinggi. Jika arus kas berfluktuasi tajam maka persistensi laba akan semakin rendah.

Dalam penelitian yang dilakukan Fanani (2010) memberikan hasil bahwa volatilitas arus kas berpengaruh negatif terhadap persistensi laba. Namun, dalam penelitian yang dilakukan oleh Asma (2013) memberikan bukti bahwa aliran arus kas berpengaruh signifikan positif terhadap persistensi laba, hal yang sama juga ditemukan oleh Ulfah (2008).

H1: Volatilitas Arus Kas Berpengaruh Positif Terhadap Persistensi Laba.

\section{Volatilitas Penjualan Dan Persistensi Laba}

Penjualan adalah bagian terpenting dari siklus operasi perusahaan dalam menghasilkan laba. Volatilitas yang rendah dari penjuaan akan menunjukkan kemampuan laba dalam memprediksi aliran kas di masa yang akan datang (Purwanti, 2010). Menurut Dechow \& Dichev (2002) volatilitas penjualan adalah derajat penyebaran penjualan atau indeks penyebaran distribusi penjualan perusahaan. Volatilitas penjualan mengindikasikan fluktuasi lingkunan operasi dan kecenderungan yang besar penggunaan perkiraan dan estimasi, menyebabkan kesalahan estimasi yang besar sehingga menyebabkan persistensi laba yang rendah. Hasil penelitian yang dilakukan oleh Purwanti (2010) dan Arfan (2018) menunjukkan bahwa volatilitas penjualan berpengaruh positif terhadap persistensi laba. Sedangkan penelitian yang dilakukan oleh Fanani (2010) memberikan bukti bahwa volatilitas penjualan berpengaruh negatif terhadap persistensi laba.

H2: Volatilitas Penjualan Berpengaruh Positif Terhadap Persistensi Laba. 


\section{Siklus Operasi Dan Persistensi Laba}

Menurut Subramanyam (2013), siklus operasi merupakan jumlah waktu dari komitmen atas kas pada pembelian hingga diperoleh kas yang berasal dari penjualan barang atau jasa. Siklus ini merupakan proses di mana perusahaan mengubah kas menjadi asset jangka pendek dan kembali menjadi kas sebagai bagian aktivitas operasi yang sedang berjalan. Untuk perusahaan manufaktur, hal ini mencakup pembelian bahan baku, mengubah bahan baku menjadi produk jadi, dan kemudian menjual dan menagih kas dari piutang.

Dechow \& Dichev (2002) berpendapat bahwa perusahaan yang memiliki siklus operasi yang lama dapat menimbulkan ketidakpastian, estimasi dan kesalahan estimasi yang makin besar yang dapat menyebabkan persistensi laba yang rendah. Siklus operasi yang lebih lama menyebabkan ketidakpastian yang lebih besar, membuat akrual lebih terganggu (noise) dan kurang membantu dalam memprediksi aliran kas dimasa yang akan datang. Fanani (2010) menemukan bukti bahwa siklus operasi tidak memiliki pengaruh terhadap persistensi laba. Ditemukan bukti yang sama dalam penelitian yang dilakukan oleh Susilo \& Anggraeni (2016) bahwa siklus operasi tidak memiliki pengaruh dan negatif terhadap persistensi laba. Sedangkan, dalam penelitian Fauzia \& Sukarmanto (2015), berpendapat bahwa siklus operasi memiliki pengaruh positif terhadap persistensi laba. Hal ini dimungkinkan untuk perputaran yang terjadi di dalam perusahaan retail memiliki siklus yang cepat.

H3: Siklus operasi berpengaruh negatif terhadap persistensi laba.

\section{Tingkat Hutang Dan Persistensi Laba}

Sumber modal suatu perusahaan erat kaitannya dengan hutang. Hutang merupakan salah satu cara untuk mendapatkan tambahan pendanaan dari pihak eksternal, dengan menjalin ikatan kontrak dengan kreditur sebagai konsekuensi perusahaan. Kemampuan perusahaan dalam memperoleh laba tidak dapat terlepas dari sumber modal perusahaan dalam mengembangkan usahanya dan menghasilkan laba yang maksimal. Hutang juga mempengaruhi persistensi laba dan tingkat stabilitas perusahaan yang akan berdampak pada kelangsungan hidup perusahaan di masa yang akan datang. Tingkat hutang mendorong perusahaan untuk meningkatkan persistensi laba dengan tujuan untuk mempertahankan kinerja baik dimata auditor dan para pengguna laporan keuangan (Putri \& Supadmi, 2016).
Tingkat hutang memiliki pengaruh positif terhadap persistensi laba (Fanani, 2010). Namun, dalam ketika perusahaan berada dalam kondisi tidak baik bisa menjadikan tingkat hutang berpengaruh negatif terhadap persistensi laba seperti pernelitian yang dilakukan oleh Purwanti (2010) dan Barus \& Rica (2010).

H4: Tingkat hutang berpengaruh negatif terhadap persistensi laba.

\section{Ukuran Perusahaan Dan Persistensi Laba}

Menurut Purwanti (2010) perusahaan yang memiliki total aktiva besar menunjukkan bahwa perusahaan telah mencapai tahap kedewasaan dimana tahap ini arus kas perusahaan positif. Pada tahap ini pula perusahaan memiliki prospek yang baik dalam jangka waktu yang relatif lama. Terdapat beberapa instrument yang dapat digunakan untuk mengukur besarnya perusahaan. Seperti total penjualan, total aset, jumlah karyawan dan nilai kapitalisasi pasar. Semakin besar instrument tersebut, semakin besar pula ukuran perusahaan Nuraini (2010).

Ukuran perusahaan menjadi salah satu indikator yang digunakan untuk memprediksi perolehan laba. Ukuran perusahaan memiliki hubungan positif terhadap persistensi laba (Dewi \& Putri, 2015) yang berarti semakin besar perusahaan maka akan meningkatkan persistensi laba. Hal yang sama juga diperoleh dalam penelitian yang dilakukan oleh Nuraini (2010).

H5: Ukuran perusahaan berpengaruh positif terhadap persistensi laba.

\section{Book Tax Differnce Dan Persistensi Laba}

Menurut Martani \& Persada (2013) pada tingkat perusahaan, manajemen menghitung laba perusahaan untuk dua tujuan setiap tahunnya, yaitu tujuan untuk pelaporan keuangan berdasarkan prinsip standar akuntansi keuangan (SAK) dan pelaporan pajak berdasarkan peraturan pajak untuk menentukan besarnya penghasilan kena pajak (taxable income) atau laba fiskal. Peraturan pajak di Indonesia mengharuskan laba fiskal dihitung berdasarkan metode akuntansi yang menjadi dasar perhitungan laba akuntansi, yaitu metode akrual, sehingga perusahaan tidak perlu melakukan pembukuan ganda untuk dua tujuan pelaporan laba tersebut, karena setiap akhir tahun perusahaan diwajibkan melakukan rekonsiliasi fiskal untuk menentukan besarnya laba fiskal dengan cara melakukan penyesuaian-penyesuaian terhadap laba akuntansi berdasarkan peraturan pajak. Rekonsiliasi fiskal diakhir periode pembukuan menyebabkan 
terjadi perbedaan antara laba fiskal dan laba akuntansi.

Dalam book tax difference terdapat dua pendekatan yaitu perbedaan permanen dan perbedaan temporer. Beberapa penelitian sebelumnya telah menjelaskan dan memberikan bukti adanya hubungan pengaruh negatif book tax differences terhadap persistensi laba, seperti Kusuma \& Sadjiarto (2014) dan Asma (2013). Sedangkan, terdapat perbedaan hasil penelitian yang dilakukan oleh Asma (2013) menyatakan bahwa terdapat hubungan positif antara perbedaan laba akuntansi dan laba fiskal terhadap persistensi laba.
H6: Perbedaan permanen berpengaruh negatif terhadap persistensi laba.

H7: Perbedaan temporer berpengaruh negatif terhadap persistensu laba.

\section{METODE}

\section{Populasi}

Populasi dalam penelitian ini adalah perusahaan sektor manufaktur yang terdaftar di BEI periode 2015-2017. Pengambilan sampel dalam metode penelitian ini menggunakan metode purposive sampling dengan kriteria yang telah ditentukan, data yang diperoleh adalah sebanyak 49 perusahaan.

Tabel 1. Kriteria Sampel

\begin{tabular}{clc}
\hline No & \multicolumn{1}{c}{ Kriteria } & Jumlah Perusahaan \\
\hline 1 & $\begin{array}{l}\text { Perusahaan manufaktur yang terdaftar di BEI } \\
\text { pada tahun 2015-2017 } \\
\text { Perusahaan manufaktur yang menyajikan } \\
\text { laporan keuangan dengan mata uang Dollar } \\
\text { (\$) }\end{array}$ \\
3 & $\begin{array}{l}\text { Perusahaan manufaktur yang mengalami } \\
\text { kerugian selama periode 2015-2017 } \\
\text { Perusahaan manufaktur yang tidak terdaftar } \\
\text { secara konsisten di Bursa Efek Indonesia } \\
\text { selama 2015-2017 }\end{array}$ \\
5 & $\begin{array}{l}\text { Perusahaan manufaktur yang mengalami arus } \\
\text { kas operasi negatif selama periode 2015- } \\
\text { 2107 } \\
\text { Perusahaan manufaktur yang tidak } \\
\text { mengungkapkan informasi yang dibutuhkan } \\
\text { peneliti }\end{array}$ \\
Jumlah sampel yang memenuhi kriteria
\end{tabular}

\section{Sumber Data}

Penelitian ini mengambil sampel pada perusahaan sektor manufaktur yang terdaftar di BEI periode 2015-2017. Data yang digunakan dalam penelitian ini adalah data sekunder yaitu dimana sumber data berasal dari laporan keuangan tahunan perusahaan manufaktur yang ada di BEI yang diperoleh dari website BEI yaitu www.idx.com dan website masing-masing perusahaan.

\section{Operasionalisasi Variabel}

\section{Persistensi Laba}

Persistensi laba diukur dengan menggunakan net income before extraordinary item (NIBE) dan total assets periode sebelumnya yang di formulasikan oleh Francis (2004).

$$
\frac{\text { NIBEt }}{\text { TAit }}=\alpha+\beta \frac{\text { NIBEt }}{\text { TAit-1 }}+\varepsilon
$$

\section{Volatilitas Arus Kas}

Volatilitas arus kas adalah standar deviasi aliran kas operasi dibagi dengan total aktiva yang pernah dilakukan oleh Dechow \& Dichev (2002).

$$
\text { Volatilitas Arus Kas }=\frac{\sigma(\text { Aliran Kas Operasi }) t}{\text { Total Aktivait }}
$$

\section{Volatilitas Penjualan}

Volatilitas penjualan adalah derajat penyebaran penjualan atau indeks penyebaran distribusi penjualan perusahaan (Dechow \& Dichev, 2002).

$$
\text { Volatilitas Penjualan }=\frac{\sigma(\text { Penjualan })}{\text { TotalAktiva }}
$$

\section{Siklus Operasi}

Siklus operasi adalah periode waktu rata-rata antara pembelian persediaan dengan pendapatan kas yang nantinya akan diterima penjual atau rangkaian 
seluruh transaksi dimana suatu bisnis menghasilkan penerimaanya dan penerimaan kasnya dari pelanggan (Dechow \& Dichev, 2002). Siklus operasi dapat diukur dengan:

$$
\begin{gathered}
\text { SO }=\frac{(\text { PiutangDagang it }+ \text { Piutang Dagang it }-1) / 2}{\text { Penjualan it } / 360}+ \\
\frac{(\text { Persediaanit }+ \text { Persediaan } \text { it }-1) / 2}{\text { Harga Pokok Penjualan it } / 360}
\end{gathered}
$$

\section{Tingkat Hutang}

Tingkat hutang atau sering disebut Leverage diukur dengan menggunakan jumlah total hutang dibagi dengan total aktiva.

$$
\text { Tingkat Hutang }=\frac{\text { Total Hutang it }}{\text { Total Aktiva it }}
$$

\section{Ukuran Perusahaan}

Ukuran perusahaan diukur dengan menggunakan Log total asset setiap perusahaan.

$$
\text { SIZE = LogNatural (Assets) }
$$

\section{Perbedaan Permanen}

Pengukuran perbedaan permanen diukur dengan jumlah perbedaan permanen dibagi dengan total aset yang perhitungannya didasarkan pada rumus sebagai berikut:

$$
=\frac{\begin{array}{c}
\text { Perbedaan Permanen } \\
\text { Jumlah Perbedaan Permanen }
\end{array}}{\text { Total Aktiva }}
$$

$$
\text { Total Aktiva }
$$

\section{Perbedaan Temporer}

Pengukuran perbedaan temporer diukur dengan jumlah perbedaan temporer dibagi dengan total aset yang perhitungannya didasarkan pada rumus sebagai berikut:

$$
=\frac{\begin{array}{c}
\text { Perbedaan Temporer } \\
\text { Jumlah Perbedaan Temporer }
\end{array}}{\text { Total Aktiva }}
$$

\section{Regresi Berganda}

Dalam menguji hipotesis dalam penelitian ini digunakan analisis regresi berganda. Analisis regresi berganda digunakan untuk menguji pengaruh beberapa variabel bebas terhadap satu variabel terikat. Untuk mengetahui hubungan tersebut maka berikut adalah bentuk persamaan regresinya:

PLit = á + â1VOKit + â2VPit + â3SOit + â4THit + â5LOGSIZEit + â6PPBTDit + â7PTBTDit + eit Keterangan:

$\begin{array}{ll}\text { PL } & =\text { Persistensi Laba } \\ \text { á } & =\text { Konstanta } \\ \text { â1-â7 } & =\text { Kefisien Regresi } \\ \text { VOK } & \text { Volatilitas Arus Kas } \\ \text { VP } & =\text { Volatilitas Penjualan }\end{array}$

SO

TH = Tingkat Hutang

LOGSIZE = Ukuran Perusahaan

PPBTD $=$ Perbedaan Permanen

PTBTD = Perbedaan Temporer

\section{HASIL DAN PEMBAHASAN}

Analisis Data

Data yang digunakan dalam penelitian ini menggunakan data panel. Dalam melakukan analisis dan pengujian hipotesis penelitian ini dibantu dengan menggunakan aplikasi Eviews 9,0. Setelah dilakukan pemilihan model dengan menggunakan Uji Chow dan Uji Hausman terpilihlah Model Fixed Effcet. Untuk selanjutnya dilakukan uji asumsi klasik yang meliputi Uji Normalitas, Uji Multikolinearitas, dan Uji Heteroskedastisitas. Berdasarkan semua uji yang telah dilakukan data tersebut terbebas dari uji asumsi tersebut, sehingga dapat dilanjutkan untuk uji hipotesis dengan menggunakan model fixed effect.

\begin{tabular}{lccccc}
\multicolumn{7}{c}{ Tabel 2. Statistik } \\
\hline \multicolumn{1}{c}{ Variabel } & Mean & Median & Maximum & Minimum & Std. Dev. \\
\hline PL & 0.116170 & 0.079628 & 1.681666 & 0.000178 & 0.163261 \\
VOK & 0.125741 & 0.098146 & 0.712391 & 0.000663 & 0.119937 \\
VP & 1.178840 & 1.111807 & 11.07275 & 0.068359 & 0.969108 \\
SO & 149.9586 & 144.9102 & 389.7585 & 51.60746 & 60.04617 \\
TH & 0.392688 & 0.374656 & 1.772134 & 0.097690 & 0.200622 \\
LOGSIZE & 14.86050 & 14.63794 & 18.33547 & 11.98019 & 1.561588 \\
PPBTD & -0.002040 & 0.000669 & 0.396160 & -0.205817 & 0.043350 \\
PTBTD & 0.00104 & 0.0006244 & 0.118048 & -0.057225 & 0.022227 \\
\hline
\end{tabular}

Dari tabel di atas dapat dilihat nilai mean, median, maksimum, minimum dan standar deviasi dari masing-masing variabel. Terdapat indikator pada variabel siklus operasi yang memiliki nilai mean sebesar 149,9586 serta nilai standar deviasi sebesar 60,04617. Standar deviasi memiliki rentan yang sangat jauh dengan nilai mean jika dibandingkan dengan variabel lainnya. Hal ini menandakan bahwa data tidak homogen.

\section{Pengaruh Volatilitas Arus Kas terhadap Persistensi Laba}

Berdasarkan hasil pengujian menunjukkan bahwa volatilitas arus kas operasi berpengaruh positif terhadap persistensi laba. Diketahui nilai probabilitas menunjukkan nilai sebesar 0.0254 < á (0.05) dan diperoleh nilai coefficient sebesar 0.091719. Hasil penelitian membuktikan bahwa volatilitas arus kas operasi berpengaruh signifikan postif terhadap persistensi laba. Sehingga hasil penelitian ini sesuai dengan hipotesis yang telah dirumuskan yaitu $\mathrm{H} 1$ diterima. Pengaruh positif menunjukkan bahwa semakin tinggi fluktuasi arus kas akan semakin meningkatkan persistensi laba. Dengan adanya 
jumlah aliran kas dari aktivitas operasi yang cukup, perusahaan tidak perlu mengandalkan pembiayaan dari luar (penerbitan saham atau utang pada pihak eksternal), dengan demikian struktur modal perusaahn tetap. Laporan aliran arus kas membantu para pemakai untuk mengetahui alasan-alasan perbedaan antara laba bersih atau laba akuntansi dengan laba tunainya.

Hasil penelitian ini berbeda dengan penelitian yang telah dilakukan oleh Fanani (2010) yang menyatakan bahwa volatilitas arus kas operasi tidak mempengaruhi persistensi laba. Tetapi hasil penelitian ini sesuai dengan penelitian terdahulu yang dilakukan oleh Asma (2013) dan Ulfah (2008) yang menyatakan volatilitas arus kas operasi mempunyai pengaruh positif dan signifikan terhadap persistensi laba mengisyaratkan bahwa semakin tinggi volatilitas arus kas operasi suatu perusahaan akan meningkatkan persistensi laba yang dimiliki oleh perusahaan tersebut.

\section{Pengaruh Volatilitas Penjualan terhadap Persistensi Laba}

Berdasarkan hasil pengujian menunjukkan bahwa volatilitas penjualan berpengaruh negatif terhadap persistensi laba. Diketahui nilai probabilitas menunjukkan nilai sebesar 0.0455 < á (0.05) dan diperoleh nilai coefficient sebesar 0.029267. Hasil penelitian membuktikan bahwa volatilitas penjualan berpengaruh positif dan signifikan terhadap persistensi laba. Sehingga hasil penelitian ini sesuai dengan hipotesis yang telah dirumuskan yaitu H2 diterima. Pengaruh positif menunjukkan bahwa semakin besar volatilitas penjualan maka persistensi labanya akan semakin meningkat. Penjualan adalah bagian terpenting dari siklus operasi perusahaan dalam menghasilkan laba. Apabila terjadi manipulasi penjualan persistensi laba perusahaan akan rendah. Dengan begitu dapat disimpulkan bahwa persistensi laba mengikuti pola penjualan (Fanani,2010).

\section{Pengaruh Siklus Operasi terhadap Persistensi Laba}

Berdasarkan hasil pengujian menunjukkan bahwa siklus operasi berpengaruh negatif terhadap persistensi laba. Diketahui nilai probabilitas menunjukkan nilai sebesar 0.2344 < á (0.05) dan diperoleh nilai coefficient sebesar -9.952201. Hasil penelitian membuktikan bahwa siklus operasi tidak berpengaruh terhadap persistensi laba. Sehingga hasil penelitian ini sesuai dengan hipotesis yang telah dirumuskan yaitu H3 diterima. Namun, dalam penelitian ini tidak memberikan bukti bahwa siklus operasi berpengaruh signifikan terhadap persistensi laba. Penelitian ini konsisten dengan yang dilakukan oleh Fanani (2010), menyatakan bahwa siklus operasi tidak berpengaruh signifikanterhadap persistensi laba.

\section{Pengaruh Tingkat Hutang terhadap Persistensi} Laba

Berdasarkan hasil pengujian menunjukkan bahwa tingkat hutang berpengaruh negatif terhadap persistensi laba. Diketahui nilai probabilitas menunjukkan nilai sebesar $0.0000<$ á (0.05) dan diperoleh nilai coefficient sebesar -0.176035 . Hasil penelitian membuktikan bahwa tingkat hutang berpengaruh signifikan negatif terhadap persistensi laba. Sehingga hasil penelitian ini sesuai dengan hipotesis yang telah dirumuskan yaitu H4 diterima. Pengaruh negatif menunjukkan bahwa semakin tinggi tingkat hutang maka persistensi labanya akan rendah.

Di satu sisi, tingkat hutang suatu perusahaan akan menunjukkan kuatnya kondisi keuangan perusahaan. Namun, dari sisi yang lain, tingkat hutang dapat dipandang sebagai ukuran kinerja manajemen dalam mengelola keuangan perusahaan. Dari sisi ini, perusahaan dengan tingkat hutang rendah cenderung mengungkapkan lebih banyak informasi laba kepada pihak eksternal sebagai upaya untuk menjelaskan lemahnya kinerja manajemen. Apabila perusahaan memiliki tingkat hutang yang besar akan menyebabkan perusahaan meningkatkan persistensi laba dengan tujuan untuk mempertahankan kinerja dengan baik di mata investor dan auditor. Namun, didalam penelitian ini ditemukan bahwa ingkat hutang memiliki pengaruh negatif terhadap persistensi laba. Hal ini bisa saja terjadi karena hutang mengadung konsekuensi perusahaan harus membayar bunga dan pokok pada saat jatuh tempo, jika perusahaan tidak mampu membayar, maka akan menimbulkan resiko kegagalan sehingga laba yang diperoleh perusahaan akan lebih diutamakan untuk membayar hutang dan bunganya daripada untuk memelihara penghasilan perusahaan dan membiayai kegiatan operasional perusahaan, sehingga akan memungkinkan berdampak pada penurunan laba perusahaan di masa depan (Barus \& Rica, 2010). Hasil penelitain ini konsisten dengan penelitian yang dilakukan oleh Purwanti (2010) dan Barus \& Rica (2010) yang menyatakan bahwa tingkat hutang berpengaruh negatif terhadap persistensi laba.

\section{Pengaruh Ukuran Perusahaan terhadap} Persistensi Laba

Berdasarkan hasil pengujian menunjukkan bahwa ukuran perusahaan berpengaruh positif terhadap persistensi laba. Diketahui nilai probabilitas menunjukkan nilai sebesar $0.0000<$ á (0.05) dan 
diperoleh nilai coefficient sebesar 0.114113 . Hasil penelitian membuktikan bahwa ukuran perusahaan berpengaruh signifikan positif terhadap persistensi laba. Sehingga hasil penelitian ini sesuai dengan hipotesis yang telah dirumuskan yaitu $\mathrm{H} 5$ diterima. Pengaruh positif menunjukkan bahwa semakin besar ukuran perusahaan maka persistensi labanya akan meningkat.

Penelitian ini konsisten dengan penelitian yang dilakukan oleh Septavita (2016) yang menyatakan bahwa ukuran perusahaan berpengaruh positif terhadap perusahaan. Semakin besar ukuran perusahaan, akan semakin baik pula persistensi laba.

\section{Pengaruh Perbedaan Permanen terhadap Persistensi Laba}

Berdasarkan hasil pengujian menunjukkan bahwa perbedaan permanen berpengaruh negatif terhadap persistensi laba. Diketahui nilai probabilitas menunjukkan nilai sebesar $0.6712<$ á (0.05) dan diperoleh nilai coefficient sebesar -0.042153. Hasil penelitian membuktikan bahwa perbedaan permanen tidak berpengaruh negatif terhadap persistensi laba. Sehingga hasil penelitian ini sesuai dengan hipotesis yang telah dirumuskan yaitu H6 diterima. Pengaruh negatif menunjukkan bahwa semakin tinggi perbedaan permanen maka persistensi labanya akan rendah tapi tidak ditemukan tingkat signifikansi terhadap persistensi laba. Penelitian ini konsisten dengan Kusuma \& Sadjiarto (2014) menyatakan bahwa book tax differences berpengaruh negatif terhadap persistensi laba.

\section{Pengaruh Perbedaan Temporer terhadap Persistensi Laba}

Berdasarkan hasil pengujian menunjukkan bahwa perbedaan temporer berpengaruh negatif terhadap persistensi laba. Secara parsial dengan uji $\mathrm{T}$ diketahui nilai probabilitas menunjukkan nilai sebesar $0.0000<$ á (0.05) dan diperoleh nilai coefficient sebesar -0.415284 . Hasil penelitian membuktikan bahwa perbedaan temporer berpengaruh signifikan negatif terhadap persistensi laba. Sehingga hasil penelitian ini sesuai dengan hipotesis yang telah dirumuskan yaitu H7 diterima. Pengaruh negatif menunjukkan bahwa semakin tinggi tingkat perbedaan temporer maka persistensi labanya akan rendah. Penelitian ini konsisten dengan Kusuma \& Sadjiarto (2014) menyatakan bahwa book tax differences berpengaruh negatif terhadap persistensi laba.
Tabel 3. Hasil Regresi Berganda

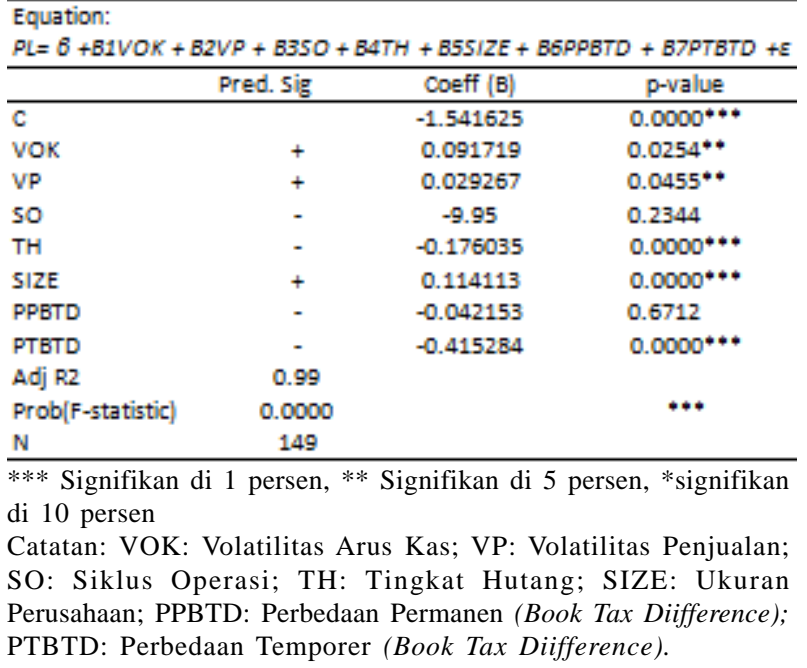

\section{SIMPULAN DAN SARAN}

Berdasarkan hasil analisis data dan pengujian hipotesis yang telah dilakukan dapat ditarik kesimpulan bahwa volatilitas arus kas, volatilitas penjualan dan ukuran perusahaan berpengaruh postif dan signifikan terhadap persistensi laba, untuk tingkat hutang dan perbedaan temporer berpengaruh negatif dan signifikan terhadap persistensi laba. Sedangkan, siklus operasi dan perbedaan permanen tidak berpengaruh terhadap persistensi laba.

\section{DAFTAR PUSTAKA}

Arfan, N. B. 2018. Pengaruh Volatilitas Arus Kas, Volatilitas Penjualan, Besaran Akrual, Dan Faniancial Leverage Terhadap Persistensi Laba. Jurnal Akuntansi Pascasarjana Universitas Syiah Kuala, 3(April), $1-12$.

Asma, T. N. 2013. Pengaruh Aliran Kas dan Perbedaan antara Laba Akuntansi dengan Laba Fiskal terhadap Persistensi Laba. Jurnal Akuntansi Universitas Negeri Padang, 1(1), 1-16.

Barth, M. E., \& Hutton, A. P. 2003. Analyst Earnings Forecast Revisions and the Pricing of Accruals Tuck School of Business at Dartmouth Accruals. Business, (02), 59-96.

Barus, A. C., \& Rica, V. 2010. Analisis Faktor-Faktor Yang Mempengaruhi Kualitas Laba Pada Perusahaan Manufaktur Di Bursa Efek Indonesia Tahun. JUrnal Wira Ekonomi Mikroskil, Vol.4(No.2), 71-80.

Dechow, P. M., \& Dichev, I. D. (2002). The quality of accruals and earnings: The role of accrual estimation errors. Accounting Review, 77(SUPPL.), 35-59. https://doi.org/10.2139/ssrn.277231.

Dewi, N. P. L., \& Putri, I. G. A. . A. D. (2015). Pengaruh Book-Tax Difference, Arus Kas Operasi, Arus Kas Akrual, Dan Ukuran Perusahaan Pada Persistensi Laba. Jurnal Akuntansi Universitas Udayana, 101, 2302-8556. 
Fanani, Z. (2010). Analisis Faktor-Faktor Penentu Persistensi Laba. Jurnal Keuangan Akuntansi dan Keuagan Indonesia, 7(1)

Fauzia, E., \& Sukarmanto, E. (2015). Pengaruh Keandalan Akrual dan Siklus Operasi terhadap Persistensi Laba pada Perusahaan Retail Trade yang Terdaftar di Bursa Efek Indonesia. Skipsi

Jensen, M. C., \& W. H. Meckling. (1976). Theory of the Firm: Managerial Behavior, Agency Costs and Ownership Structure. Journal of Financial Economics, 3, 305-360.

Kusuma, B., \& Sadjiarto, R. A. (2014). Analisa Pengaruh Volatilitas Arus Kas , Volatilitas Penjualan, Tingkat Hutang, Book Tax Gap , dan Tata Kelola Perusahaan Terhadap Persistensi Laba. Tax \& Accounting Review, 4(1), 1-8.

Martani, D., \& Persada, A. E. (2013). Pengaruh Book Tax Gap terhadap Persistensi Laba. Jurnal Manajemen Dan Kewirausahaan, 1(1), 1-132. https://doi.org/ 10.9744/jmk.13.2.91-98

Nuraini, M. (2010). Analisis Faktor-Faktor Penentu Persistensi Laba.Skipsi.

Purwanti, T. (2010). Analisis Pengaruh Volatilitas Arus Kas, Besaran Akrual, Volatilitas Penjualan, Leverage,
Siklus Operasi, Ukuran Perusahaan, Umur Perusahaan, dan Likuiditas Terhadap Kualitas Laba, $1-71$.

Putri, G., \& Supadmi, N. L. (2016). Pengaruh Tingkat Hutang dan Kepemilikan Manajerial Terhadap Persistensi Laba Pada Perusahaan Manufaktur. E-Jurnal Akuntansi Universitas Udayana, 15(2), 915-942.

Schipper, K., \& Vincent, L. (2003). Earnings Quality. Accounting Horizons, Supplement, 97-110. https:/ /doi.org/10.2308/acch.2003.17.s-1.97.

Septavita, N. (2016). Pengaruh Book Tax Differences, Arus Kas Operasi, Tingkat Hutang, Dan Ukuran Perushaan Terhadap Persistensi Laba. JOM Fekon, (2007), 1309-1323.

Subramanyam, K.R \& Wild, John J. (2010). Analisa Laporan Keuangan. Jakarta: Salemba Empat.

Susilo, T. P., \& Anggraeni, B. M. (2016). Analisis pengaruh volatilitas arus kas, tingkat utang, siklus operasi, dan ukuran perusahaan terhadap persistensi laba, 6.

Ulfah, M. N. \& M. (2008). Analisis Pengaruh Arus Kas Operasi Terhadap Harga Saham Dengan Persistensi Laba Sebagai Variabel Intervening.Jurnal Maksi, 74-86 